\title{
O JOGO DE ESPERANÇA E DESESPERO EM A MORATÓRIA, DE JORGE ANDRADE
}

\author{
Carlos Eduardo Monte ${ }^{132}$
}

RESUMO: $O$ presente trabalho pretende analisar a importância da obra do dramaturgo paulista Jorge Andrade (1922-1984), A moratória, no panorama do teatro nacional, procurando evidenciar qual a importância da mesma para a construção de nossa identidade, a partir de uma escrita que conjuga aspectos rurais e econômicos, e que traz como principal aspecto o plano social de conversão ideológica que se verifica a partir de 1930, como analisa Antonio Candido, em seu texto Literatura e desenvolvimento. $\mathrm{O}$ pano de fundo de A moratória fixa-se em dois planos temporais, 1929 e 1932, e seus personagens estão perdidos nessa conversão temporal e existencial, capaz de pôr em xeque valores sedimentados, em detrimento da crua realidade que arruína a aristocracia paulistana dona dos cafezais no interior do estado. Comparado em parte com a dramaturgia de Anton Tchekhov, sobretudo com O jardim das cerejeiras, A moratória reúne elementos que dão sólidos contornos a um tipo de drama capaz de incorporar com especificidade as fontes rurais raramente trabalhadas em nossa literatura, ligando-se a produção crítica que, a partir de 1950, abandona de vez o ideal do país novo.

Palavras-chave: Teatro brasileiro; Jorge Andrade; A moratória; Identidade nacional.

ABSTRACT: The present article intends to analyze the importance of Jorge Andrade's work, a São Paulo's playwright (1922-1984), A moratória (The Moratorium), in national theater's panorama, trying to evidence what is the importance of it to the construction of our identity, from a written that combines rural and economics aspects, and which has as main aspect the social plain of ideological conversion which occurs from 1930 on, as analyzes Antonio Candido, in his text Literature and development. The background of A moratoria is fixed in two temporal planes, one at 1929 and the other at 1932, and their characters are lost in this temporal and existential conversion, able to put in check sedimented values, over the cross fact that ruins São Paulo's aristocracy, owner of the coffee plantation

${ }^{132}$ Doutorando em Estudos Literários pelo Programa de Pós-graduacao em Estudos Literários da Universidade Estadua Paulista Júlio de Mesquita Filho - UNESP/ARARAQUARA 
at the countryside of this state. Compared partly with the dramaturgy of Anton Tchekhov, especially with O jardim das cerejeiras (The Cherry Orchard), A moratoria brings together elements that give solid outlines of a kind of drama able to incorporate with the specificities the rural sources rarely used in our literature, binding to the critical production that, from 1950, abandons for once the ideal of new country.

Keywords: Brasilian theater; Jorge Andrade; A moratoria; National identity.

Há mais de sessenta anos, exatamente em 06 de maio de 1955, a peça A moratória, de Jorge Andrade era encenada pela primeira vez em São Paulo, no Teatro Maria Della Costa. Recepcionada com entusiasmo pelo público, A moratória representava a convergência entre a incorporação das fontes rurais a um mercado teatral em crescimento e ávido por novos talentos; representava, também, por seu conteúdo, a inscrição da escrita social que sedimentava de vez o contexto de crise que no passado proporcionou uma virada epistemológica, a partir de 1930, como observa Antonio Candido, em análise dos estudos de Mario Vieira de Mello (CANDIDO, 1989, p. 139).

Ao lado de O telescópio, A moratória deixava transparecer a virtude da entrega autêntica e da tematização naturalizada pelo autor de origem rural e interiorana - onde, aliás, Jorge Andrade viveu a maior parte de sua vida. Enquanto no plano literário as maiores proezas sociais reclamavam na crise canavieira a melhor ambientação narrativa, Jorge Andrade enxergava com extrema perspicácia o paralelo paulista da hecatombe, priorizando a encenação da decadência da aristocracia arruinada pela crise do café. A marca de Jorge Andrade está no diálogo direto, pouco apocopado, com a mestria que alcança o drama reflexivo e a superficialidade do homem fragmentado, recorrendo ao lírico e ao épico, o que se vê é que "[...] além do mérito artístico, a intransigente honestidade com que foram escritas as peças e a absoluta ausência de concessão ao sensacionalismo" (MAGALDI, 2004, p. 228), Andrade construiu uma obra como poucas vezes vista em nossas terras.

Além da temática pessimista, em que passado e futuro tomam o lugar do presente, alijando a dramaturgia rigorosa que o teatro clássico de Schiller, por exemplo, havia conquistado em observância aos vetores que podem ser destacados a partir da Poética de Aristóteles, Jorge Andrade não se atém as leis unitaristas de ação, tempo e espaço, ou tampouco a organização que vai da harmonia à desarmonia, adensando-se sua tensão 
no conflito dramático através da dramaturgia dialógica, para, então resolver-se pela catarse; pela purificação ou pela purgação do herói trágico. Em A moratória, sobretudo pela inocorrência da atualidade - atuação no presente e em presença, capaz de garantir a absolutez da obra de arte teatral - ressoa em palco nacional algo próximo do que a obra do russo, Anton Tchékhov, convertia na virada do século, mas precisamente em 1904, com a famosíssima $\mathrm{O}$ jardim das cerejeiras, em que uma família da aristocracia russa, agindo sob o signo da renúncia, como reivindica Peter Szondi (2011), se vê incapaz de livrar sua propriedade do fatídico leilão que converterá o jardim das cerejeiras - um símbolo de contemplação - em um operacional cerejal a ser devastado em razão do novo ideário russo. De fato, o teor lírico que se revela em Tchekhov, não tem o mesmo fôlego em Jorge Andrade. Se Liubov, Gaév e as irmãs Ânia e Vária, faziam ouvidos moucos a seu destino, ignorando a fala vaticinal de Lopakhin, implantando um ambiente de dispersão, no qual verdadeiros diálogos monológicos depunham a fala ensimesmada de um grupo de anti-heróis, em Jorge Andrade há a prevalência do diálogo direto e insistente, o qual, inclusive, torna-se, como artifício retórico, uma fórmula tautológica de esboroar a trama e clarificar a crise. Assim, embora em um primeiro momento as peças se assemelhem tematicamente - a idade de ouro que se representa pelo cafezal/cerejal preste em ser exterminado, dando lugar ao novo - o homem de Tchékhov ampara-se mais na estética da fragmentação, colimando forma e conteúdo; não temos atos, mas fragmentos em Tchekhóv e, em essência, a peça ganha perspectiva pelo silêncio e pela solidão estrutural em que cada um de seus personagens vive; assim, embora rodeado por outras pessoas, as longas pausas e o desencontro dos diálogos monológicos, ganham virtudes na mestria proporcionada pelo teatro da ilusão do qual Stanislavski (1863. 1938) talvez seja o maior representante, como fundador do Teatro de Arte de Moscou, com quem Tchekhov viveu uma espécie de irmandade criativa, capaz de testar no teatro toda sorte de know-how tecnológico, então jamais visto.

Mas, se Jorge Andrade não alcança Tchekhov pela prevalência do individuo em seu desespero e angústia interior, A moratória constrói, em três atos completamente anacrônicos, com perfeição a decadência da aristocracia paulista, e põe em primeiro plano os estertores de sua existência, ante o incontornável progresso econômico capitalista, que não poupa ou escolhe vítimas. "Situando a peça em dois planos e a ação nos anos de 1929 e 1932, Jorge Andrade quis deixar bem marcada a queda irremediável da aristocracia rural" (MAGALDI, 1996, p. 229), assim, a peça 
parece se encaixar como uma luva às palavras de Antonio Candido, ao fixar nos anos 30 a época de uma virada cultural que, literariamente, porá em evidência a passagem da esperança ufanista em que se apoiava o povo do país novo, cujo futuro se projetava de forma certa e inexorável, animando terra e pátria, até a quebra gradativa dessa metanarrativa que, em multiplicidade, começa a ser implodida pela desalentadora realidade de um país plantado na realidade de mazelas e subdesenvolvimento.

Para Décio de Almeida Prado, a obra de Jorge de Andrade é uma amostra no nível familiar da transição entre classes:

"A moratória" evoca o fim, frequentemente melancólico, desse processo social: a divisão e perda das fazendas, com a ascensão de novas classes, facilitada por dois violentos choques: a crise do café e a revolução de trinta (ambos, não é preciso acrescentar, extremamente benéficos à democratização do País). Não compreenderá nada do alcance da peça quem não pressentir, por detrás dos indivíduos e dos episódios particulares que ela narra, a agonia de uma sociedade em vias de transição - aquela dolorosa passagem do Brasil dos fazendeiros para o Brasil urbano tão bem descrita por Gilberto Freyre (ALMEIDA PRADO, 1993, p. 11).

Jorge Andrade compreendeu muito bem esse zeitgeist que se adensa em 1930, e que a partir de 1950 se alastra em nossa literatura. Dá-nos, assim, a realidade direta, o que faz da sua escrita reiterados atos em que os determinismos locais parecem não funcionar a uma razão coronelista, pela qual o poder politico cada vez mais perde terreno para o poder econômico. Tão plena a consciência do autor, que a peça pode ser lida pelo constante jogo da Esperança - ou, em rasura social, pela alusão constante do País Novo - versus Desespero, como a verdade que se descortina a fim de se deixar a ver a realidade social do país colonizado e subdesenvolvido.

\section{BEM-VINDO AO...}

1.1. ...Futuro!

JOAQUIM: Venha tomar o café.

LUCÍlLIA: Agora não posso.

JOAQUIM: O café esfria. 
LUCÍLIA: Meu serviço está atrasado.

JOAQUIM: Ora, minha filha, cada coisa em sua hora.

LUCÍLIA: Para quem tem muito tempo.

JOAQUIM: Não é preciso trabalhar assim. Tudo tem um limite.

LUCÍLIA: Sou obrigada a trabalhar como uma... (Contém-se) (ANDRADE, 1993, p. 24).

Joaquim é o pai de família que espera aflito pelo resultado de uma ação judicial que já se arrasta, como toda chicana jurídica, por mais de três anos. A ação tem como objeto anular a venda da fazenda onde a família havia residido por mais de trinta e cinco anos. Diante de uma crise econômica crescente, Joaquim se vê obrigado em efetuar reiterados empréstimos bancários e a terceiros que também não conseguem saldar sua divida. A esposa, Helena, após a crise torna-se uma beata fervorosa e faz da reza sua tábua de salvação, sem nada entender sobre o destino dos negócios. Marcelo é o filho que jamais se importou em aprender qualquer coisa que estivesse ligada a fazenda; como o tipo bon-vivant, após a crise torna-se o bêbado mulherengo, capaz de enredar a mãe para conseguir algum dinheiro. Por fim, a irmã, Lucília, é a única com possibilidades psíquicas de manter os pés na realidade; sem se deixar levar pelo discurso esperançoso do pai, pela cantilena religiosa da mãe, ou pelas engenhosas escusas do irmão, utilizando-se do que havia aprendido como diletante, ela passa ao trabalho exaustivo para poder dar aos pais o mínimo de dignidade.

Dono de um diálogo que corta como navalha, Jorge Andrade é extremamente cuidadoso no desenvolvimento de seu texto secundário. Com ele, o texto principal, do qual acima destacamos a cena inicial, em que pai e filha procuram uma convergência, encaixa-se em uma trajetória temática repleta de vai-e-vens que só serão freados pelo colapso final, quando toda a esperança é perdida. Antes de conhecermos as primeiras falas da peça, Andrade é minucioso na descrição que preenche duas páginas com explicações acerca do cenário e das ações que deverão compor sua obra.

O cenário divide o palco em dois planos: o direito, fixado em 1932, denominado como sendo o Primeiro Plano; e o esquerdo, em 1929, onde estará situado o Segundo Plano; a ação, portanto, em dois tempos distintos. No plano direito, já em 1932, a sala modesta, com móveis simples e desgastados, adornada com motivos religiosos católicos, prevalecendo à mesa de refeições e a de costura, com a porta abrindo-se para outros 
cômodos, fazendo-nos entender que a família está alocada fora da fazenda, habitando uma casa simples; no segundo plano, concentrado no passado da ação, uma sala espaçosa e cheia de isotopias nababescas, tudo a representar "uma antiga e tradicional fazenda de café" (ANDRADE, 1993, p. 22).

O trecho que lemos acima se dá no primeiro plano, ou seja, em 1932, na pequena casa, após a crise, e marca a primeira cena da peça. Após a ruína familiar, a filha Lucília, tornou-se arrimo de família, trabalhando com costura para poder sustentar, além dos pais, Joaquim e Helena, também ao irmão Marcelo que não se encaixa em função alguma como se tomado por uma espécie de acídia ou embotamento inafastável. $\mathrm{Na}$ antirrotina temporal, Joaquim, o pai atrelado aos costumes, mediocremente anovelado em sua antiga força coordenadora, esvazia frases de efeito em tom professoral: Cada coisa em sua hora, e reitera o discurso de que tudo se ajeitará, graças ao resultado do processo que está prestes em ser anunciado, pelo qual retomará seu cafezal e honra. Pouco a pouco, seu discurso transforma-se em uma cantilena patética e absurda, e Lucília parece ser a única capaz de lidar com as exaltações do pai, esforçando-se para sanar as necessidades familiares, abrindo mão de sua própria vida.

Particularmente, nesta cena, Lucília costura o vestido que tia Elvira - irmã de Joaquim, produtora de café, e que ainda não foi afetada pela crise - usará na festa do Coronel Bernardino, uma festa para qual a família de Joaquim foi convidada apenas por educação, como preço a ser pago como símbolo do derrotismo social que ora representa. A nova vida, que significa o extrato do subdesenvolvimento, já que a verdadeira ruína está na incapacidade, e também nas desventuras climáticas e econômicas que arruinaram o cafezal, propriedade da família. Tudo ficou no passado; o pai volta-se para o passado, e vê no futuro uma possibilidade de retomá-lo; a mãe apoia-se na reza, e preocupa-se em manter a estrutura familiar, aconselhando marido e filhos através do viés tradicional. Enquanto, no presente, Lucília se acaba entre alfinetes, amostras e tecidos.

O futuro que o pai espera, em que "[...] é preciso guardar as aparências" (idem, p. 73), já é o futuro na peça:

JOAQUIM: Há de chegar o dia em que vai poder ir a todas as festas novamente. E de cabeça erguida.

(...)

JOAQUIM: Com a nulidade do processo, vou recuperar a fazenda. Darei a você tudo que desejar. (idem, p. 28). 
LUCÍLIA: Não vamos falar nisto.

JOAQUIM: Por que não? Eu quero falar.

LUCÍLIA: É bom esperar primeiro a decisão do Tribunal.

JOAQUIM: (Impaciente) $\mathrm{O}$ mal de vocês é não ter esperança. Essa é que é a verdade.

LUCÍlLIA: E o mal do senhor é ter demais. (idem, p. 29) Grifamos.

E,

JOAQUIM: (Exaltando-se) O meu partido nunca fez o que o P.R.P. fez.

LUCÍLIA: Para mim são todos iguais.

JOAQUIM: É por causa deles que nós, lavradores, estamos nesta situação.

LUCÍLIA: Ora, papai, o senhor sabe que isto não depende de partidos. Crise é uma coisa à parte. (p. 67).

\section{2. ...Passado!}

E assim, logo Jorge Andrade nos leva ao passado, onde de fato está concentrado o conflito dramático da peça. Aqui, a família ainda aproveita os últimos louros de uma vida rica, centrada na produção cafeeira, cujo espaço é marcado pela sala enorme, cheia de móveis e adornos portentosos. O filho, Marcelo, se dá ao luxo da boemia; a filha, estereótipo da época, aprimora seus ducados à espera do melhor casamento. Esse passado que está guardado no segundo plano da peça, sedimenta um realismo psicológico pelo qual entrevemos o temor de ver tudo se perder. O cafezal torna-se intrínseco ao seio familiar, de tal forma que o discurso de pais e filhos revela um amor até então não anunciado pela terra, estrategicamente veiculado pelo simbolismo que a tradição representa. É o que lemos em:

LUCÍlLA: Meu sentimento de família e de felicidade está ligado às nossas terras. Em minha família foi sempre assim. Não aprendi a sentir de outra maneira. É esta a única realidade. (idem, p. 140).

Ou, também: 
JOAQUIM: Muito! Os antigos eram de peso.

(..)

JOAQUIM: (Pausa) Foi presente de casamento de meu avô ao meu pai. Sabe? Meu avô tinha um propósito. Os antigos não davam nada assim sem mais nem menos. Sabiam que sempre o que era mais útil. Junto com o presente veio a recomendação: "Meu filho! Não deixe nunca o sol pegar você na cama e saiba dividir o seu tempo que tudo..." Disto ninguém poderá me acusar, Helena. Em toda minha vida, só aquela vez quando tive maleita, não vi o sol nascer (p. 157 e 162).

Quando, no Segundo Plano, as luzes se acendem, marido e mulher estão no passado, em 1929. Encontrando a esposa na sala, Joaquim nos dá notícias da crise que se avizinha. Sem falar diretamente sobre o problema, esboça circunstâncias de risco, pondo em curso um discurso que se reiterará e se fortalecerá a cada dia: "Se continuar assim, não sei onde vamos parar! Não chove, não pode haver café. Não há mais café como antigamente. Basta olhar o cafezal para desanimar. Não chegamos ainda ao ponto de esmolar! Minha fazenda é uma garantia. Eu sei defender meus negócios" (idem, p. 37-39). Estas são frases lapidares que saem da boca do administrador emocional e economicamente desestruturado que Joaquim se tornou. Não bastará a experiência que lhes deram seus antepassados; exemplos e costumes avoengos perdem-se em um mundo remoto, dos quais são subtraídas apenas frases de efeito que não ecoam em funcionalidade com o presente capitalista que se impõe.

A anacronia do texto, com suas analepses e prolepses contínuas, nos responde a pergunta de Joaquim: "[...] não sei onde vamos parar?", logo no início da peça: o futuro reserva a perda da fazenda, do cafezal e também das jabuticabeiras. Em uma cena absolutamente bem construída, com alternância constante entre os planos, será a tia Elvira quem anunciará a decadência dos cafezais. Vamos a ela:

ELVIRA: Vamos atravessar uma grande crise.

JOAQUIM: (Primeiro plano) Lucília!

HELENA: (Segundo plano) Crise?

ELVIRA: O café caiu a zero.

JOAQUIM: (Primeiro plano) Lucília!

HELENA: (Segundo plano) (Aturdida) Caiu? 
ELVIRA: Os lavradores foram abandonados pelo Governo. LUCÍLIA: (Primeiro plano) (Entrando) Que foi, papai? HELENA: (Segundo plano) Não é possível! JOAQUIM: (Primeiro plano) Minha filha! (Joaquim fica olhando para Lucilia sem poder falar)

ELVIRA: (Segundo plano) O Governo não pode sustentar a política de defesa do café e... (idem, p. 82-83, grifamos)

O passado tomou-lhes a fazenda, o presente toma-lhes o futuro.

Os antepassados de Joaquim desbravaram a terra ainda nua, contanos o protagonista em suas falas memorialistas; por mais que se esforce, a vida do homem do campo agora se vê atrelada a outros fatores com o qual não sabe necessariamente lidar. Tudo está em vias de se perder, em uma ciranda anunciada. Arlindo, um outro dono de terras, toma dinheiro emprestado de Joaquim para tentar salvar sua plantação, o que não ocorre, o que o leva a fugir para endereço desconhecido; Joaquim, sem receber de Arlindo, é devedor junto ao banco e outros credores. Inexoravelmente, a fazenda deverá ir à praça. Em uma cena de constrangimento, Helena roga à Elvira que, juntamente com seu marido, Augusto, arremate a fazenda, a fim de que o marido, Joaquim, possa continuar nela trabalhar e, quiçá, vir a quitar a dívida em contrapartida, retomando o bem. Despindo-se de todo orgulho, Helena não é atendida pela cunhada, a qual, em cena futura, será confrontada pela sobrinha, Lucília, por não ter contribuído com seus pais, quando a família mais precisava.

A realidade do país, que não soube salvaguardar seus produtores, encerra um contínuo de esfacelamento dos negócios, dentro de um efeito dominó. À esperança de Joaquim, contrapõe-se o tempo que segue inexorável. Cartulas e promissórias vencem sem que possam ser quitadas. A moratória concedida (em um primeiro momento tão celebrada), pouco a pouco se torna um pesadelo, em razão das safras que não vingam, resultando apenas no crescimento desenfreado da dívida, cada vez mais difícil de ser solvida.

\section{2. “O BRASIL É O PAÍS DO FUTURO!”}

À oposição país novo versus país subdesenvolvido, através da qual Candido desenvolve o capítulo Literatura e desenvolvimento, presente no livro A educação pela noite $\mathcal{G}$ outros ensaios (1989), amolda-se com rara 
perfeição à peça A moratória, sendo um destes casos em que a teoria pode ser lida pela obra literária. Segundo escreve o autor, a partir das reflexões do diplomata e teórico Mário Vieira de Mello, "[...] a ideia de país novo produz na literatura algumas atitudes fundamentais derivadas da surpresa, do interesse pelo exótico, de um certo respeito pelo grandioso e da esperança quanto às possibilidades." (CANDIDO, 1984, p. 40). A ideia operante, sobretudo no século XIX, trazia em seu bojo a razão de um país que deveria ser exaltado pela sua possibilidade de potência - ufanismo, utopia e ideário Romântico imbricam-se em comunhão a fim de suplantar atrasos sociais - sendo capaz de ser convertida, no plano literário, como um forte campo de discurso, pelo qual se desdobrava a euforia latente na busca pela afirmação nacional: "A literatura se fez linguagem de celebração e terno apego, favorecida pelo Romantismo, com apoio na hipérbole e na transformação do exotismo em estado de alma. O nosso céu era mais azul, as nossas flores mais viçosas, a nossa paisagem mais inspiradora que a de outros lugares [...]" (idem, p. 141).

Na peça em tela, recebemos impressões de seus personagens que são capazes de colimar uma espécie de realismo psicológico, o qual se desdobra do naturalismo realista que se prende na transformação afetiva que se tem pela terra em um simples objeto a ser comercializado. A possibilidade de afirmação de elementos formadores de uma identidade nacional ligava-se a uma episteme que estabelecia um bloco semântico a partir da união entre as noções de pátria e terra, o que seria, em outras palavras, suficiente para a função transformadora, presente na ideia de progresso contínuo que a perspectiva país novo rendia. Sendo essa, então, a primeira perspectiva, ela não tardaria a ser rechaçada de forma inexorável pelos primeiros decênios do século XX, em que as ditas transformações culminaram com um cenário econômico medíocre, acertado por repetidas crises que eram enfrentadas pela então chamada aristocracia brasileira. Nessa esteira, Candido escreve:

Mário Vieira de Mello, um dos poucos que abordaram o problema das relações entre subdesenvolvimento e cultura, estabelece para o caso brasileiro uma distinção que também é válida para toda a América Latina. Diz ele que houve alteração marcada de perspectivas, pois até mais ou menos o decênio de 1930 predominava entre nós a noção de "país novo", que ainda não pudera realizar-se mas que atribuía a si mesmo grandes possibilidades de progresso futuro. Sem ter havido modificação essencial na distância que nos separa dos 
países ricos, o que predomina agora é a noção de "país subdesenvolvido". Conforme a primeira perspectiva salientava-se a pujança virtual e, portanto, a grandeza ainda não realizada. Conforme a segunda, destaca-se a pobreza atual, a atrofia; o que falta, não o que sobra (CANDIDO, 1989, p. 140).

O outro lado da medalha, como escreve Candido, era tenebroso, nele "[...] as visões desalentadas dependiam da mesma ordem de associações, como se a debilidade ou a desorganização das instituições constituíssem um paradoxo inconcebível em face das grandiosas condições naturais [...]" (idem, p. 141). A terra bela não seria mais convertida em pátria grande, e a consciência de país subdesenvolvido altera a perspectiva de glória, transformando-a no pessimismo que dará força ao leitmotiv denuncista contra aquela metanarrativa ideológica que se escondia nas impressões de pais novo, e que agora era o motor de voz dos intelectuais.

A consciência do subdesenvolvimento é posterior à Segunda Guerra Mundial e se manifestou claramente a partir dos anos de 1950. Mas desde o decênio de 1930 tinha havido mudança de orientação, sobretudo na ficção regionalista, que pode ser tomada como termômetro, dadas a sua generalidade e persistência. Ela abandona, então, a amenidade e curiosidade, pressentindo ou percebendo o que havia de mascaramento no encanto pitoresco, ou no cavalheirismo ornamental, com que antes se abordava o homem rústico. Não é falso dizer que, sob este aspecto, o romance adquiriu uma força desmistificadora que precede a tomada de consciência dos economistas e políticos. (idem, p. 141).

A moratória poderia ser tomada como opera omnia dessa tomada de consciência no que se refere à produção teatral brasileira. Por um lado, sua primeira encenação data de 1955; por outro, o ano de 1930 está exatamente no centro da temporalidade de sua trama, que percorre de 1929 a 1932, indo da famosa Quebra da Bolsa de 29 a Revolução Constitucionalista. Ao dissecar o mecanismo de ruína de uma das mais representativas promessas de nosso crescimento, no campo agrícola, Jorge Andrade nos proporciona uma difusão de comportamentos daqueles que, 
em primeiro plano, são afetados pelo declínio econômico do país: os donos do cafezal. Quando olhamos para Joaquim (ou Quim, o pai), Helena (a mãe), Lucília (a filha) e Marcelo (o filho) - ou seja, para os quatro membros dessa célula familiar em meio ao redemoinho - constata-se uma diversidade de reações formativas-comportamentais, um múltiplo que corresponde ao espírito do mundo em crise, no qual reina a desorientação dos que sempre puderam contar com as propriedades para solucionar problemas tanto na ordem privada, como na pública, pela cultura do coronelismo.

Em 1929, Lucília é aprendiz de costureira. Viaja constantemente a cidade, onde tem um namorado, Olímpio, o jovem advogado que, apesar de filho de um inimigo político de Joaquim, espera uma resposta a sua proposta de casamento. Enquanto a mãe considera o aprendizado de Lucília uma diversão, o pai recrimina o contato com costureirinhas: "Sabe-se lá quem frequenta esses cursos. Gente de toda espécie." (p. 59), comenta Joaquim. Além do mais, o pai também desaprova o namoro com Olímpio: "Então só porque é advogado pode casar com minha filha? (...) Quero saber de quem é que filho. Isso sim é importante. (...) Esses doutorzinhos só sabem falar. Aposto que não sabe nem olhar a idade de um cavalo!" (idem, p. 60-61). Ironicamente, agora em 1932, a filha trabalha noite e dia costurando vestidos para tentar dar aos pais uma vida menos miserável, e, ao tempo em que vê no casamento com Olímpio, a quem verdadeiramente ama, a única solução imediata para seu estado aflitivo, teima em não assumir o compromisso com medo de que os pais morram à míngua e totalmente desamparados.

Em 1929, o momento é de expectativa; neste plano, a crise anunciada se avizinha a passos largos, mas a família vive ainda apenas uma perspectiva de mudança, certos de que o quadro pessimista não lhes acertará diretamente, Joaquim, ou simplesmente Quim, recorre a uma moratória para procrastinar o pagamento de suas dividas, o que lhe é concedido por prazo determinado, sem que a situação desalentadora possa ser contornada. É preciso dizer que há um arco divisório entre os planos e encimando-o está a genialidade de uma única peça que serve tanto a um como a outro plano: ponderando o elemento implacável e imperativo da trama, o grande relógio subverte simbolicamente o tempo que se apressa inexorável e marca as diferenças entre 1929 e 1932. Encenando, alternadamente, os dois planos, o que vemos é o presente do passado e, como efeito dos atos das personagens, sua resultante, pelo presente do futuro. 
Em 1932, Marcelo, que em 1929 aparecia como um produto do dolce far niente, agora é um bêbado que gasta o pouco dinheiro que consegue emprestado da mãe com prostitutas; seu trabalho em um frigorifero, a única função que consegue realizar com alguma satisfação, está à milhas de distância do que se espera do filho de fazendeiro que deveria levar adiante o nome e as riquezas da família. No passado, em 1929, ainda é um jovem completamente irresponsável, que está sempre sendo chamado de um sono constante. Busquemos esse contexto:

HELENA: Marcelo!

MARCELO: (Voz) Senhora.

HELENA: Levante-se, meu filho. Seu pai já chamou.

MARCELO: Já estou de pé.

HELENA: É preciso que você vá à cidade.

MARCELO: (Aparece acabando de se vestir) O que aconteceu hoje nesta casa?

HELENA: Nada. Por quê?

MARCELO. Todo mundo quer que eu me levante, conversar comigo. O que foi?

HELENA: Já é hora, meu filho. (idem, p. 40-41).

Ou em:

JOAQUIM: Venha cá.

MARCELO: Tenho pressa.

JOAQUIM: Eu também. Tem pressa por quê? Quem tem pressa não dorme até esta hora.

MARCELO: Vou a cidade.

JOAQUIM: Sente-se. Vamos conversar.

MARCELO: Agora não posso, papai.

JOAQUIM: Pode. Pode. Eu digo que pode.

MARCELO. Não podemos conversar à noite?

JOAQUIM: Não, senhor. Tem que ser agora. Sente-se.

MARCELO: De que se trata?

JOAQUIM: Quero saber até quanto pretende continuar nesta vadiagem? (idem, p. 56).

Marcelo abandonou todos os estudos que começou; admite abertamente o seu descaso e insucesso intelectual: "Não dou para os 
estudos"; "Não sei fazer nada"; "Nunca trabalhei"; "Não sei frear meu pensamento"; "Não sei viver preso", e etc. Sua fala é colimada por um comportamento de descompromissos, pelo exercício de um hedonismo implacável. Como filho de um fazendeiro e rico dono de terras, não se vê obrigado enredar-se nos negócios da família, senão apenas para cobrar a parte da mesada. Nesse aspecto, Marcelo é o personagem que mais se aproxima dos personagens que compõem $O$ jardim das cerejeiras. Mesmo diante da crise que se abre, mostra-se como um personagem que não age, que nada faz, e que nem mesmo pensa objetivamente sobre o assunto, dando à ação dramática a característica da dispersão.

Joaquim e Marcelo formam a chave para o entendimento da peça.

Aquela que deveria ser a geração da continuidade, dando sequência aos fortes valores avoengos e passados, claramente plantados em Joaquim, na verdade, assimila a crise a partir de um ideário derrotista; assim, pela voz de Marcelo percebemos de forma gritante a ruptura de que nos fala Cândido, quando se instaura a crise da esperança, pela ideia de país novo, e o advento do desespero, pela realidade do subdesenvolvimento. Para os homens de 1930, como Marcelo, não havia mais razões para uma vida dedicada exclusivamente ao trabalho ou grande valor na formação familiar, posto que, em um plano maior, dentro do grande panorama econômicosocial, o que se via era uma desvelação de metanarrativas que haviam sido gradativamente forjadas, e que agora não poderiam mais se sustentar. Para esse novo homem, incapaz de lutar contra uma poderosa roda econômica que traz a lume a miséria de nossas vidas, não há motivos para sacrificar o que considera seus pequenos prazeres para o dia e para a noite, ora representados pela bebida e pelo sexo.

Joaquim é o pai da família. O dono de terras que vê tudo se deteriorar de uma hora a outra; crente de que suas manobras comerciais, todos os empréstimos bancários, poderiam evitar a bancarrota do cafezal, ele não admite que a esposa ou qualquer outra pessoa lhe aconselhe. $O$ tipo ruralista, embora dono de um farto conhecimento dentro de seu meio, agora se mostra incapaz de lidar com um mundo novo que lhe bate a porta, cobrando alto o preço por uma política econômica subdesenvolvida. Aqui, a marca de uma inexperiência administrativa em oposição a uma ordem de valores inexpressivos frente ao mundo capitalista. Esse homem do campo, que viu sua riqueza ser construída, se vê confrontado tanto na esfera pública, como na privada.

Andrade realiza de forma impecável a transição: particular para o geral; geral para o particular. As isotopias nos dão o plano geral; sabemos da 
falência do cafezal, da inexperiência do governo, das altas dividas bancárias, etc. Mas, é no microcosmo, na vida íntima da família, é que está concentrada a base dessa representação, pela perda do agônico.

Longas cenas são gastas para enxergarmos a impossibilidade do diálogo entre pai e filho. Joaquim e Marcelo não podem se entender, há uma diferença paradigmática abismal entre eles. $O$ pai não consegue fazer alcançar ao filho o prêmio que tem nas mãos, daquilo que julga ser a grandiosidade de seus atos, a razão de sua existência, pela transmissão dos costumes que absorveu do discurso progressista, convergindo terra e pátria em uma mesma linha de leitura. Marcelo não sofre pela angústia da influência, como nos diria Harold Bloom; não há nele nada que faça desaparecer a cortina da ideologia que ao longo dos anos sustentou as premissas do pai. Não há honra nessa herança, mas, a completude do contrário, pelo desprezo de não saber lidar com a falência. Apaga-se a ilusão de ótica, aviva-se a realidade da miserabilidade da condição humana, dentro de uma terra desolada:

JOAQUIM: Você não honra o nome que tem.

MARCELO: (Pausa) E o que é que vale este nome?

JOAQUIM: Muita coisa. Ainda somos o que fomos.

MARCELO: Não somos nada, está é que é a verdade.

JOAQUIM: Não me confunda com você.

MARCELO: Até quando o senhor vai mentir a si mesmo? [...] Vivemos num mundo diferente [...].

MARCELO: As regras para viver são outras, regras que não compreendemos e nem aceitamos. O mundo, as pessoas, tudo! Tudo agora é diferente! Tudo mudou. Só nós que não. Estamos apenas morrendo lentamente. Mais um pouco e ficaremos como aquele ganho de jabuticabeira: secos! Secos! (idem, p. 117-118 e 122).

\section{CONSIDERAÇÕES FINAIS}

No universo de Jorge de Andrade, o país todo é uma paisagem da incapacidade.

Nada pode ser feito por nenhum de seus personagens para evitar a ruína do cafezal. Não há um litígio célula familiar versus país subdesenvolvido, porque este, por sua desestrutura política, enfatizada por um eterno senso de país colonizado, mostra-se cada vez mais vitimado pelos 
homens que chegam e procuram nunca mais deixar o poder, sempre em função de soluções pessoais de enriquecimento - tal como nossos colonizadores pensavam. $O$ país contamina seus cidadãos e a identidade que se extrai é aquela formada pela incompreensão, pela incerteza, a injustiça, o fragmentado, a pobreza, o abismo social que evidencia uma estrutura governamental que nos empurra através do terror gradativo, dentro de uma atmosfera nociva a percepção da realidade.

O medo de Joaquim, tal como o homem do alto modernismo, que presencia a ruína das grandes narrativas, pondo em xeque suas certezas e valores, reforça-se como tema genuíno do teatro brasileiro neste contexto. Conhecemos o medo não apenas por sua manifestação mais sedimentada, pela noção de inferno e trevas; em nosso mundo, vemo-nos diante de uma obscura ansiedade que nos põe à espera do indefinido, por contraditória opressão, da sensação de solidão e abandono recorrentes, em aliança com os insucessos pessoais e com as manifestações de nossa incapacidade, seja pelas doenças, pelas guerras e todas as demais catástrofes que nos afligem, aqui lido pelo desvelamento de uma cortina que impedia o conhecimento da verdade.

Na Rússia de Tchekhov, o jardim das cerejeiras estava para a família, como o país estava para o povo. No Brasil, de 1930, o cafezal está para a família, também como o país está para o povo. Nos dois contextos, a terra e a pátria formam uma simbologia em contraste: há terra, mas não há pátria. A terra, a cerejeira e o cafezal, que em um primeiro momento é o espaço da contemplação, resultado de um ideário construtor-progressista, assume um caráter meramente produtivo, sujeito a leis mercadológicas capazes de esvaziar-lhe a essência, e fixar um preço em seus limites. A moratória deve ser entendida como a ruína representativa de um projeto que atravessa séculos de racionalidade científica; na inversão de Jorge Andrade, ninguém escapa à força destrutiva do capitalismo, sobretudo aqueles que se prontificam a ele, confluindo para um efeito de realidade que se perde em devaneio, dando novos contornos a identidade brasileira.

Enquanto mestres da literatura trabalham um país subdesenvolvido a partir de noções regionalistas, como Graciliano Ramos ou Guimarães Rosa, experimentando esteticamente a produção mimética da realidade, a fim de obter como resultado obras monumentais e uma espécie de ápice literário hiper-realista, Jorge Andrade, décadas mais tarde, realoca o tchekhovismo, a fim de evidenciar a crise do próprio sujeito, alcançando uma realização que aproxima sua obra do épico e também do lírico, digna 
de ser lida como uma das mais audaciosas realizações dramáticas já realizadas em terras nacionais.

A moratória só poderia lançar mão de dois planos - passado e presente - para traduzir a procura do autor. $\mathrm{O}$ passado, com a perda da fazenda, ainda não concluíra o retrato da família e era necessário, assim, pintá-la na vida medíocre da cidade, tentando em vão recuperar as posses antigas. As ideias e os movimentos das personagens não se adaptaram às novas condições de existência e, para anunciar a constante psicológica, o texto joga com uma certa atemporalidade: sugere-se um conflito no presente e ele será desenvolvido no passado, como se fosse o futuro, porque naquele mundo nada se altera de fato (MAGALDI, 2004, p. 232-233).

Devemos entender que o movimento de entropia para qual caminhou o Modernismo afirma a ocorrência de um momento limítrofe, resultando em um Spätzeit - conceito historiográfico alemão que trabalha com fatores operacionais, identificadores de transformações que não podem ser desconsideradas, fatores que alinham, como no Zeitgeist, as mais variadas esferas de uma cultura complexa, pondo em questão a produção artística dentro de um contexto social. Barthes (informa-nos Compagnon, 2010), considerava a literatura moderna opressiva, culturalmente exigente, cobrando de um leitor atento, intelectualmente ativo, o exercício de reconhecer sua validade formal, que funcionava como receptor daquele formalismo. O teatro de Jorge de Andrade aparece em divergência à maioria das obras literárias do Modernismo, as quais persistiam na linearidade narrativa, em constante recordação vetorial da poética de Aristóteles, dentro de uma equação que era tão lógica quando a produção evolutiva do conhecimento. Dessa forma, os elementos narrativos de representação cumpriam, na sua grande maioria, fatores fundamentais, exaustivamente recombinados, objetivando: a instauração, o desenvolvimento e desfazimento. As realizações miméticas correspondiam à dada estrutura, emprestando de grandes cestos teóricos, como o Formalismo Russo e o Estruturalismo, a tentativa ordenada e consciente de produzir, encaixando tudo em mosaicos narrativos pré-estabelecidos.

Essa questão, bem recepcionada pela crítica contemporânea, está no contexto de que trata a peça de Andrade e clarifica uma espécie de 
Spätzeit ${ }^{133}$ opressivo ao homem, pela perda de energia - tendo como referencial argumentativo a Idade de Ouro e a ideia do Paraíso Perdido -, pela decadência, pela saturação cultural, pela secundariedade e pela posterioridade, mas que se torna traço fundamental em uma virada estratégica na forma de conhecer o país, processo que, embora iniciado nos anos trinta e quarenta, alcançará seu ápice a partir dos anos 50 , do século passado. O efeito da razão, com que o homem havia se acostumado, que tinha como pressuposto uma lógica formalizada, perde-se vertiginosamente, dando lugar a desorganização psicológica, moral e social, resultando em um colossal inferno astral em que a espera se torna a forma branda e eufemística do nada, fazendo do homem um ser para o nada.

Em alguns trechos de A moratória, não apenas a aproximação com o teatro de Tchekhov que impressiona, mas também a lida com o presente que se furta à técnica analítica revelando passado-futuro como incapacitação de possibilidades:

LUCÍliA: Ela não se cansa de falar na ajuda que nos dá e nas dificuldades que todo mundo está atravessando.

JOAQUIM: (Incomodado) Sua mãe não devia ficar tanto tempo na igreja!

LUCÍLIA: Ou achou melhor trazer pessoalmente, para não esquecermos que devemos favores a eles. Aposto como vai contar a luta que teve para conseguir um pouco de café!

JOAQUIM: (Olha para Lucilia durante um instante, contrai o rosto e abaixa a cabeça)

LUCÍliA: A verdade é que ela deve ter a consciência bem pesada.

JOAQUIM: Por quê?

LUCÍLIA: O senhor não se lembra mais?

JOAQUIM: (Levanta-se) Não preciso deles para recuperar o que é meu.

\footnotetext{
${ }^{2} \mathrm{O}$ termo Spätzeit, conforme explica Walter Moser, é de dificultosa tradução, mas designa o periodo de encerramento de uma época: Segundo explica: "Proponho-me engarjar-me aqui numa exploração do campo designado por esse termo. Começarei por associá-lo a um substantitivo que já atingiu o estatuto de um conceito historiográfico: Spätzeit. $O$ fato de empregá-lo na sua versão alemã pode indicar que são, sobretudo, historiadores de língua alemã que se serviram dele, mas mostra também meu embaraço de tradutor. Como traduzir Spätzeit? "época tardia" não é corrente, "tempo da decadência" é restritivo demais, "o tempo que chega tarde" literal demais. Trabalharemos, pois, com o termo alemão como a sigla de alguma coisa que resta precisar" $(1999$, p. 33).
} 
LUCÍLIA: Um dia hei de dizer tudo isso a ela.

JOAQUIM: (Saindo para a cozinha) As colheitas andam más. (Só a voz de Joaquim) Não há mais café como antigamente.

LUCÍlLA: Não se esqueça de que a fazenda deles tem setecentos mil pés de café.

JOAQUIM: (Voz) Que adianta? Não chove!

LUCÍlLIA: Enfim, é sempre a mesma coisa: chuva, chuva! (Toca a máquina) Quando morávamos na fazenda, a ladainha era a mesma. (Paua) $\mathrm{O}$ que sei é que preciso trabalhar se quisermos viver, pelo menos decentemente. (Joaquim aparece na porta em arco no Segundo Plano; está de perneiras e traz um chicote na mão) (idem, p. 32-33).

O velho homem, preso há uma identidade modernista, traz um chicote nas mãos. Com ele, na qualidade de velho recurso, pretende domar o presente; seus inimigos, credores, opositores e filhos deverão a ele alguma reverência. No mínimo, os setenta anos de Joaquim, que o fizeram um experiente administrador de terras, devem ser considerados como o substrato da época em que a terra e pátria imbricavam realizações de sucesso e orgulho. O novo homem, claramente representado pelo filho Marcelo, onde a juventude e a pouca experiência é confundida como atributos irmãos do desinteresse pelas coisas do campo, olha por outra janela, que não aquela em que o pai contempla o cafezal. Marcelo vê apenas uma briga de gigantes, cujos pés arrastam-se para cá e para lá, desfazendo todo o cafezal, e quase já em vias de pisar-lhe a cabeça.

\section{REFERÊNCIAS}

ALMEIDA PRADO, D. História concisa do teatro brasileiro. São Paulo: Editora da Universidade de São Paulo, 2008.

ANDRADE, J. A moratória. 13a ed. Rio de Janeiro: Agir, 1993.

CANDIDO, A. Literatura e subdesenvolvimento. In: . A educação pela noite e outros ensaios. São Paulo: Ed. Ática, 1989. p. 140-162. 
COMPAGNON, A. O mundo. In: . O demônio da teoria. Literatura e senso comum. Trad. de Cleonice Paes Barreto Mourão e Consuelo Fortes Santiago. 2a ed. Belo Horizonte: Editora UFMG, 2010. p. 95-135.

. O trabalho da citação. Trad. de Cleonice P. B. Mourão. Belo Horizonte: UFMG, 1996. p. 11-36.

FISCHER, L. A. Dicionário de palavras $\mathcal{E}$ expressões estrangeiras. Porto Alegre: L\&PM, 2004.

SZONDI, O. Teoria do drama modern. Trad. de Raquel Imanishi Rodrigues. 1a ed. São Paulo: Cosac Naify, 2011.

MAGALDI, S. Incorporação das fontes rurais. In: Panorama do teatro brasileiro. 6ª ed. São Paulo: Global, 2004. p. 228-235.

MOSER, W. Spätzeit. In: . Narrativas da modernidade. Org. de Wander Melo Miranda. Belo Horizonte: Autentica, 1999. p. 33-54.

ROSENFELD, A. Teatro moderno. São Paulo: Perspectiva, 1977.

Recebido em: 25/04/2016

Aceito em: 12/06/2016 